Article

\title{
"She Did Not Notice Me": Gender, Anxiety, and Desire in The Reluctant Fundamentalist
}

\author{
Suzy Woltmann
}

Literature Department, University of California, San Diego, CA 92093, USA; kwoltman@ucsd.edu

Received: 26 July 2018; Accepted: 23 October 2018; Published: 25 October 2018

\begin{abstract}
Using the recent trend in literary scholarship that theorizes literature in terms of globalization, cosmopolitanism, and dialectic transnational identities, I examine gender and sexual ideology in Mohsin Hamid's 2007 novel The Reluctant Fundamentalist, a post-9/11 text that explores the intricacies of community and terror. Specifically, I argue that the novel articulates a particularly gendered vision of spatial, social, and political (im)mobility through the narrator's desires, especially as demonstrated through his romantic interest, and masculine anxieties expressed through his response to American imperialism. The narrator's view of the United States is inexorably tied to his projection of convoluted desire, and he conflates impotence with frustration at being unable to respond to growing American militaristic power. We as readers wish to identify with a protagonist whose story we slowly learn is largely articulated in terms of his sexual desire and denial: we at first empathize with his desire but then, when discovering its projection is problematic, simultaneously wish to reject it. The interplay of the microcosm of an individual's failed romantic relationship and the macrocosm of countries at conflict mimics the mobility and liminality of conflicting ideologies.
\end{abstract}

Keywords: gender and sexuality; globalization; terrorism; masculinity; imperialism

Using the recent trend in literary scholarship that theorizes literature in terms of globalization, cosmopolitanism, and dialectic transnational identities, I examine gender and sexual ideology in Mohsin Hamid's 2007 novel The Reluctant Fundamentalist, a post-9/11 text that explores the intricacies of community and terror. Specifically, I argue that the novel articulates a particularly gendered vision of spatial, social, and political (im)mobility through the narrator's desires, especially as demonstrated through his romantic interest, and masculine anxieties expressed through his response to American imperialism. The narrator's view of the United States is inexorably tied to his projection of convoluted desire, and he conflates impotence with frustration at being unable to respond to growing American militaristic power. We as readers wish to identify with a protagonist whose story we slowly learn is largely articulated in terms of his sexual desire and denial: we at first empathize with his desire but then, when discovering its projection is problematic, simultaneously wish to reject it. The interplay of the microcosm of an individual's failed romantic relationship and the macrocosm of countries at conflict mimics the mobility and liminality of conflicting ideologies.

The Reluctant Fundamentalist has been given extensive analytic treatment in terms of family, nationality, and class, but it has rarely been approached from a gender studies angle. Anna Hartnell finds that while the novel portrays the war on terror as another form of US imperialism, it also allows room for a projected egalitarian future America. Peter Morey argues that the novel functions in a space of refusal: just as the narrator defies categorization, so too does the text itself. While most post-9/11 novels are either trauma narratives or an exploration of warring cultures, The Reluctant Fundamentalist instead exposes narrative truth only through the lens of defamiliarization, which forces us to identify with the deterritorialized subject (Morey 2011, p. 35). In a discussion of civilization and globalization in the novel, Adnan Mahmutovic concurs with this assessment, arguing that the text 
"adds complexity" to the post-9/11 genre (Mahmutovic 2016, p. 2). Citizenship here is analogous to what Ayesha Ahmed explores as the concept of belonging. The novel depicts belonging as ethically transgressive. Just as citizenship and belonging are dependent on the intersectionality of "family, gender, nationality, class mobility, and social power" (Jameson 1986, p. 69), so too is the novel an exploration of where these structures intersect. Other scholars have focused on Erica as a pivotal metaphor, but her position as a woman is usually subsumed into a larger discussion of international relations and globalization. My reading explores the portrayal of gender, anxiety, and desire as they relate to the novel's nationalist discourse.

The Reluctant Fundamentalist is a novel that continually challenges classifications of identity while simultaneously affirming them. The narrator, Changez, is born and raised in Pakistan and acculturates to collegiate and corporate America before becoming disillusioned in the wake of the 9/11 attacks. He addresses a "you" who is both an enigmatic American granted no vocal space within the text and also a reader: Hartnell describes the addressee as "wholly silent" (Hartnell 2010, p. 38). The second-person narration in The Reluctant Fundamentalist navigates the liminal space between authoritative and internally persuasive discourse. Authoritative discourse gains its power from existing at a remove from the individual; it comes from no-place, no-time, and infinite power. Conversely, internally persuasive discourse invites dialogism because it is "half ours and half someone else's" (Bakhtin 1981, p. 582). As Gardner argues, the novel's second-person narration subverts the normative Orientalist dynamic - the West in a place of power and voice and the East as an inferior silenced other (Gardner 2016, p. 109). Instead, the book "gives voice to the othered ... while silencing the traditionally empowered" (Gardner 2016, p. 109). The very form of the novel encourages internally persuasive dialogue and dialogism, since we witness different thoughts, worldviews, and motivations than our own. However, the interpellating "you" of the unknown stranger Changez addresses-the "you" that is both us as a reader and ominous stranger-conversely forces us to identify with a singular subject and gives Changez authoritative potency. This conflation once again affirms Hartnell's interpretation that the novel operates in a space of resistance and, as Morey contends, makes us as a reader also resist. We empathize with Changez and the "you", and simultaneously feel alienated from both. This forces the reader to question their own versions of cultural truth and ideological interpellation.

I use Rebecca Walkowitz's argument that spaces of "isolation as well as solidarity" in texts such as these invoke multilingualism, translation, and translatability as a platform to look not only at language production, but also at the production of gender and sexual ideologies in this text (Walkowitz 2015, p. 166). In Born Translated, Walkowitz asserts an "ambiguous intimacy" inherent in the second-person narration of this novel because the addressee is "a person whose gender and nationality are unmarked" (Walkowitz 2015, p. 167). Yet I find the "you" to be an implied American and, significantly, a man. The second-person narration allows the novel to "seem translated, written for someone else, from the start" (Walkowitz 2015, p. 167). Though the novel does allow for a more dialogic mode of understanding than more authoritative formats, even when experiencing a sense of intimacy in second-person narration, the reader still experiences the double remove of the text being written by the author and narrated by the fictional character-and the hailed "you" being separate from the reader. To Walkowitz, this novel allows for "a surfeit of possible relationships-professional, sexual, geopolitical—between readers and texts" (Walkowitz 2015, p. 167). This plurality of possible relationships creates a liminal space in which we identify with many of the novel's characters. We are always aware that the narrator is talking to us, the narrator is not the author, and we are and simultaneously are not the addressee. This forced estrangement also forces us to think about the space between the signifier (narrator/author) and signified (stranger in cafe/reader), which parallels that same space in linguistic form. The space between is where translation occurs, and in this novel translation is not only a cultural and linguistic phenomenon, but also a gendered one. Like culture and language, gender is something we use to categorize ourselves, and Changez's masculinist anxieties and proprietary treatment of Erica show that to him, something is lost in translation. 
The narrator of The Reluctant Fundamentalist seems to be welcoming the American stranger to his country by telling him a story about his own experiences in America. This narrative is constructed through continual references to problematic longing. Changez says he grew up "with a poor boy's sense of longing" (Hamid 2007, p. 71), and this longing permeates his narrative and his sense of self. His love interest Erica seems to represent Changez's projected many-pronged desires: she fits into Princeton collegiate society with ease, and the many parties and events in Manhattan that she brings Changez to show a sort of luxuriant cosmopolitanism that he desires for himself. In a more aggressive way than through his other friendships, degree from Princeton, or position at the prestigious Underwood Samson company, Changez seeks recognition and belonging through Erica - or at least his flat understanding of what he wants her to be. Much of Erica's and Changez's attraction and communication is founded in cultural difference. He is excited by looking at her "wheat-colored limbs" (Hamid 2007, p. 26), and she enjoys hearing stories about his childhood in Pakistan. Yet Erica longs for her now-deceased first boyfriend Chris, who was very similar to her. They spent their childhoods together and planned to spend the entirety of their lives together, and in him, she recognized a sense of home. Changez attempts to appropriate this home in several ways. When he visits Erica after working with a prestigious financial firm, he feels "at home" while in her literal home (Hamid 2007, p. 51), but even this is disrupted by the specter of American masculinity: Chris' painting hangs on her wall, and her father denigrates Pakistanis to an offended Changez.

Changez invites the addressee to gaze with him at women walking by, and compares their Western, overtly sexual attire with the women in "traditional dress" at the table nearby (Hamid 2007, p. 16). He uses this gaze and implied cultural binarism as a device so that he can begin to discuss his preferred gazing subject: Erica, Changez's only romantic interest given any narrative space, who he finds "enormous satisfaction" in watching (Hamid 2007, p. 21). His projection of desire onto the fellow Princetonian is directly correlated to his desire to be accepted and successful in America, and her later rejection becomes representative of Changez's slipping social and financial station following the 9/11 attacks. "(Am)Erica" becomes "a heavy-handed allegorical figure" who "personifies the narrator's romantic national investments, his ill-fated love affair with American life" (Medovoi 2011, p. 654). Changez first describes Erica in a nearly rapturous tone in the discourse of sexual desire and a broader longing that permeates his narrative. He is the seeing subject and she the viewed object broken into fetishistic parts rather than a whole person. Her hair "piled up like a tiara on her head" is reminiscent of the Statue of Liberty (Hamid 2007, p. 17). To believe he is a successful candidate for Erica's love, Changez feels the need to disqualify his potential rivals in terms of their masculinity. A man serenading Erica is "meagerly muscled" and ultimately "posed no threat" (Hamid 2007, p. 18). Though another contender seems to have more success, Changez finds comfort in his continued observation of and gazing at the object of his desire. In fact, he even goes so far as to assign blame for his gaze to Erica herself, who "forced" him to stare at her when she took off her top to sunbathe (Hamid 2007, p. 23). This stare becomes the catalyst for their friendship, and Changez extrapolates this sexual gaze at the female body to a wider nationalistic difference by describing disparities of desire in America and Pakistan.

Even through Changez's narrative lens, his sexual encounters with Erica are uncomfortable and predatory at best. The first time begins in a celebratory manner, as Erica has finally acquired an agent to help publish her novella. Changez's language when describing this encounter signifies Erica's extreme unresponsiveness to his exertions: she did not "respond" or "resist" but instead "merely acceded," and is mostly "silent and unmoving" and obviously unaroused (Hamid 2007, p. 89). Rather than reading this as a sign that Erica does not want sex at that moment and pulling back, Changez instead internalizes her lack of desire as a "growing wound ... inflicted on my pride" (Hamid 2007, p. 89). Later, he reads her silence after the 9/11 attacks as "inconsideration" rather than stopping to think that she perhaps has her own trauma to handle (Hamid 2007, p. 102). Changez so wants Erica to be the ideal woman he built up in his imagination and through his gaze that he becomes hurt when she functions outside of this projected paradigm; he wants the Erica he created rather than the Erica that is. 
Their second and final time sleeping together is even more disturbing than the first. Although Erica at first says she does not want to go home with Changez, he insists until "she finally did acquiesce" (Hamid 2007, p. 104), and when she is once again unresponsive in bed, he asks her to pretend he is Chris. Finally, they have passionate sex, but Erica is imagining her dead American male lover while Changez is watching the dissolution of his perceived perfect woman. This encounter has a potent violent charge to it: Changez likens her vagina to a wound, continuously smells blood, and recognizes afterwards that he may have "done Erica some terrible harm" (Hamid 2007, p. 106). Following this encounter, Erica retreats into a debilitating depression and Changez becomes disillusioned with his work at Underwood Samson.

In the most perplexing part of this narrative recounting, Erica disappears from a rehabilitation center. She is likely dead, but her disappearance has a mysterious and mystical quality to it, as she leaves behind her clothes but no body. Like an otherworldly being, she simply disappears into thin air. Ahmed reads that Changez's desire for Erica is contingent on the "violence of his unrequited longing" (Ahmed 2017, p. 2), since his desire for her is also an impotent desire to belong, and since her sense of belonging is forever ruptured by Chris's death. Instead of finding solace in coming together and perhaps finding belonging with each other, these two broken individuals are only reminded of the violence of their not-belonging. Erica represents "a shame-filled and apologetic America," which implies that shame and vulnerability can be as powerful as dominance (Gardner 2016, p. 110). She "becomes the one aspect of America to which Changez remains loyal, even after his apparent fundamentalist shift" (Gardner 2016, p. 110). It is significant that Changez's only loyalty is to a woman and that her life ends in suicide. Gardner describes this in terms of Judith Halberstam's "shadow feminism" (Halberstam 2011, quoted in (Gardner 2016, p. 110)), or the ways in which feminist agency does not necessarily need to operate in terms of subversion but rather can operate in spaces of sacrifice and self-harm. In this text, the normally silenced subject-the Pakistani immigrant-has a voice as the narrator, and the liberal Western woman does not. By having Erica's life end in a supposed suicide, the novel implies that she resists normative masculinist analysis. Erica's very suicide is an act of resistance: "In ending her existence as a wealthy, White, heterosexual woman who benefits from America's refusal to accept responsibility for its consequences, Erica models an unwillingness to live as such for others and for her government as well" (Gardner 2016, p. 111).

Erica's mother gives Changez her novella, who finds he cannot "locate Erica in the rhythms or sounds of what she had written" (Hamid 2007, p. 166). After he knows she is likely dead and so the object of his desire will never come to be a substantial part of his reality, Changez still experiences surprise at the gap between his own projection of desire and who Erica actually was. Erica seems to exist only to teach Changez a lesson. What that lesson is remains patently unclear, however, as the narrator vacillates between the "fundamentalist" ideals of quantity and financial strength espoused in the corporate world of Underwood Samson and a less fundamental whimsy he finds in his relationship with Erica, which functions as a foil to his more rigid values. Once Erica disappears, however, Changez loses that balance. A body would be too tangible for Changez's understanding of Erica; instead, it is almost as if she never even existed. And perhaps for Changez's sake, it is almost as if she did not, although he continues to wait for Erica, just as she waited for Chris. Yet this parallelism, rather than demonstrating the romantic desire to be with his loved one, instead illuminates the liminality of Changez's existence: between being accepted by American society and being shunned, between secular and religious, between home and away, and finally between life and death.

Although Changez's gender and sexual ideologies are largely articulated through his desire for Erica, they also take place in his attempts to assert an identity that challenges normative American notions of masculinity. The name Changez means "change," and the changes that take place in Changez's life cause him anxiety and ultimately cause him to change himself from US corporate cog to anti-American protester. Further, Changez is "Urdu for Genghis Khan" (Hamid 2007, quoted in (Medovoi 2011, p. 653)), a historical masculine figure known for not only his military force, but also his virility. Walkowitz finds an "Orientalist narrative" prevalent in The Reluctant Fundamentalist 
(Walkowitz 2015, p. 199), and I wish to build on that identification. Edward Said (1979) asserts that the Western imperial subject creates the Eastern subject as s feminized other. Historically, the West has exoticized, eroticized, fetishized, and infantilized the East. The Orient becomes textualized and canonized through a series of ascribed traits of eroticized women, effeminate men, and all throughout a notion of the Orient as an immutable other. This ideology informs Changez's understanding of masculinity and causes him to resist American power structures. He sees that Pakistan is crumbling in response to imperialistic America. In the wake of the imperialist gaze, it becomes weak, which Changez's perspective implies is feminine and therefore undesirable.

Changez attempts to assert his masculinity throughout his narrative recounting. His story begins when he addresses the stranger/reader with "excuse me, sir" and asks the addressee not to be alarmed by his beard (Hamid 2007, p. 1). This "sir" interpellates the reader to identify with a masculine persona, which becomes important as we realize Changez's anxieties around gender and desire. Changez then establishes himself as a "lover of America" (Hamid 2007, p. 1). Already Changez's narrative about his disillusionment with the United States' sociopolitical climate is established as something that he interprets and internalizes through gender and sexual discourse. We know from these first lines that the speaker and his companion are male, and the qualification that he is "a lover" indicates the troubled sexual interplay that will become fleshed out later in his recollection. Changez immediately constructs a paradigmatic value system that conflates financial prowess and militaristic force with a masculine American virility - one which he seeks, however implicitly, to destabilize, by recreating America as penetrable and feminine. At first, the American stranger seems to be hostile, and the Pakistani narrator "hospitable" (Walkowitz 2015, p. 192). America occupies its usual space as an imposing imperial force, and Changez appears to adapt a feminine domestic interiority. Yet these dynamics alter throughout the course of the narrative, as "the narrator assumes that role" (Walkowitz 2015, p. 193). Changez's tenuous masculinity, so caught up in a futile romantic endeavor and destabilized by American social and political violations, is reclaimed through his retelling of its loss and his move from receptive host to aggressor. As Walkowitz says, the novel encourages us to see the ways in which some narratives are "more visible (or audible) than others" (Walkowitz 2015, p. 193), and historically the masculine realm has more visibility. Changez goes on to mention the waiter's "intimidating" looks (Hamid 2007, p. 6), which Walkowitz references to demonstrate the active translation taking place as the narrator speaks to the nameless addressee (Walkowitz 2015, p. 191), but which I also read as implying his tenuous grasp on desired masculinity.

Changez seeks to construct himself through masculine doubles. Although his foil is Erica, he has "two recurring doubles in the novel—his boss Jim (originally from a poor, working-class Midwestern family) and his Caribbean colleague Wainwright" (Medovoi 2011, p. 647). Later, he encounters a non-American driver and a bookseller, which Medovoi reads as representing a structural triangulation away from the Pakinstani-US binary. Changez never empathizes with Erica, but instead seeks to define himself in terms of financial prowess, public space, politics, and finally, other men. He "had thrown in my lot with the men of Underwood Samson, with the officers of the empire" (Hamid 2007, p. 152), when all along he believes he was never accepted and therefore was never a true man in their eyes. This challenge to masculinity is also reflected in Changez's attack (although it also qualifies the narration of this attack to show his potential unreliability) in a parking lot for being perceived to be Arab, which turns into a very visceral display of aggression. Immediately following this assertion of masculinity, Changez delves further into his understanding of Jim, his mentor at Underwood Samson. In his description, Jim is quite obviously gay, which appears to be internalized by Changez as another threat to his masculinity. After visiting home, Changez gives voice to these thoughts and becomes "powerless ... angry at our weakness, at our vulnerability" (Hamid 2007, p. 128). He feels feminized and made impotent by American imperialistic militaristic powers, but also by its less overt envoys of financial capital and other modes of masculine anxiety. His response to the $9 / 11$ attacks is told, or rather translated, to the traveler in the language of sexual desire: he is "remarkably pleased" by witnessing "the fact that someone had so visibly brought America to her 
knees" (Hamid 2007, pp. 72-73). Here, America is definitively female, and Changez finds pleasure in her fallibility. Two masculine/phallic structures are destroyed, an act which Changez internalizes as America being "brought to her knees" in overtly sexualized and demeaning imagery. Changez views America as a "callous and brutalizing empire" (Medovoi 2011, p. 646), and as such, one aligned with the normatively masculine realms of imperialism and violence. Reconstituting the country as feminized allows him to reclaim a sense of potency.

Shortly after recounting Erica's death, Changez gets to the climactic portion of his own story: he has returned to Pakistan to become an activist and possible supporter of terrorism. Though there were several years between the events of Erica's disappearance and his own reluctant fundamentalism, the narrative space he gives it represents his own conflation of these events. The text closes with the addressee reaching into his pocket for a possible gun, which Changez hopes is instead a business card holder-but the two are "bound by a certain shared intimacy" (Walkowitz 2015, p. 184), which to Changez should preclude the penetrative force of shooting. We wonder at the end of the text if, given his seeming plan to deflect or kill his would-be assassin all along, Changez is the reliable narrator he claims to be. He self-referentially points out on several occasions the addressee's potential disbelief in his recollection of his tale, but continually claims he is telling the truth. Finally, because we ultimately realize Changez has been misrepresenting several claims-for example, the innocuousness of the muscular waiter and his desire to walk the American to his hotel-we must also question his reliability as a narrator and representor of the Changez/Erica relationship. And if we as readers are meant to inhabit the place of the American traveler, as Walkowitz argues, does it mean that Changez may kill us in the end? Walkowitz indicates that born translated literature moves away from the conceit of the singular genius author-creator by forcing us to think about movement, migration, and processes of production. Hamid widens the scope of this collaborative effect so that at the closing of the text, the reader is either killing or being killed-either penetrating or being penetrated.

To conclude, The Reluctant Fundamentalist has a "circuit of exchange" prevalent in the plot (Walkowitz 2015, p. 190), and I find this takes place in terms of gender and sexual dynamics alongside the more overt sociopolitical ones. The contemporary state of international politics requires a deeper look into issues of xenophobia, gender, and belonging. While The Reluctant Fundamentalist was first published just over a decade ago, it points to recurring issues of cultural belonging, globalization, and radicalization that still persist today. US politics have become increasingly polarized in recent years, reflecting a similarly chaotic state of global relations. President Donald Trump, as recently as January 2018, tweeted that Pakistan has "given us nothing but lies \& deceit, thinking of our leaders as fools" (Trump 2018). This kind of coarse, critical rhetoric shows a need for a more nuanced understanding of global relations. The Afghan war in Pakistan, Osama bin Laden's capture in Pakistan, and the use of United States drones to kill Pakistani militants indicate the continued need to take an intimate look at US-Pakistan relations. Further, the rise of social media and connectivity has brought a conversation about gender to the forefront of the American cultural imagination. Novels like The Reluctant Fundamentalist allow us to think through these issues and perhaps gain further understanding of intersectional identities.

Funding: This research received no external funding.

Acknowledgments: I would like to thank Winnie Woodhull for her support.

Conflicts of Interest: The author declares no conflict of interest. 


\section{References}

Ahmed, Ayesha. 2017. The Transgressions of Belonging in Mohsin Hamid's The Reluctant Fundamentalist. Tropos 4: 1-6. [CrossRef]

Bakhtin, Mikhail Mikhalovich. 1981. Forms of Time and of the Chronotope in the Novels: Notes Toward a Historical Poetics. In The Dialogic Imagination. Austin: University of Texas Press, pp. 84-258.

Gardner, Renee Lee. 2016. Suicide as an Invocation of Shame in Mohsin Hamid's The Reluctant Fundamentalist. In American Shame: Stigma and the Body Politic. Bloomington: Indiana University Press, pp. 109-24.

Halberstam, Judith. 2011. The Queer Art of Failure. Durham and London: Duke University Press.

Hamid, Mohsin. 2007. The Reluctant Fundamentalist. Boston: Mariner.

Hartnell, Anna. 2010. Moving through America: Race, Place and Resistance in Mohsin Hamid's The Reluctant Fundamentalist. Journal of Postcolonial Writing 46: 336-48. [CrossRef]

Jameson, Frederic. 1986. Third-World Literature in the Era of Multinational Capitalism. Social Text 15: 65-88. [CrossRef]

Mahmutovic, Adnan. 2016. Global Citizenship in Mohsin Hamid's The Reluctant Fundamentalist. Transnational Literature 8: 1-15.

Medovoi, Leerom. 2011. "Terminal Crisis?" From the Worlding of American Literature to World-System Literature. American Literary History 23: 643-59. [CrossRef]

Morey, Peter. 2011. "The Rules of the Game Have Changed": Mohsin Hamid's The Reluctant Fundamentalist and Post-9/11 Fiction. Journal of Postcolonial Writing 47: 135-46. [CrossRef]

Said, Edward. 1979. Orientalism. New York: Vintage.

Trump, Donald (@realDonaldTrump). 2018. “Pakistan.” 1 January, 4:12 AM. Tweet. Available online: https:/ / twitter.com/realdonaldtrump/status/947802588174577664 (accessed on 1 October 2018).

Walkowitz, Rebecca. 2015. Born Translated. New York: Columbia University Press.

(C) 2018 by the author. Licensee MDPI, Basel, Switzerland. This article is an open access article distributed under the terms and conditions of the Creative Commons Attribution (CC BY) license (http://creativecommons.org/licenses/by/4.0/). 